\title{
Translational Research of Leptin in Lipodystrophy and Its Related Diseases
}

\author{
Ken Ebihara and Kazuwa Nakao
}

\begin{abstract}
Leptin, an adipocyte-derived hormone, plays crucial roles in the regulation of energy expenditure and food intake. Through analyses of leptin transgenic mice, we have demonstrated that leptin has pleiotropic effects such as regulation of insulin sensitivity and lipid metabolism. Lipodystrophy is a disease characterized by a lack of adipose tissue, which leads to metabolic disorders including insulin resistant diabetes, hypertriglyceridemia, and fatty liver. We demonstrated that leptin deficiency plays an important role in the pathogenesis of metabolic disorders in lipodystrophy. We also demonstrated the efficacy of leptin replacement therapy in lipodystrophy. Leptin improves insulin sensitivity at least partly by cancellation of lipotoxicity in the liver and skeletal muscle. It is also possible that leptin improves insulin secretion by cancellation of lipotoxicity in pancreatic beta cells. Using animal models, we demonstrated that leptin activates hepatic AMP-activated protein kinase (AMPK), and hepatic AMPK activation is involved in the therapeutic effects of leptin. To elucidate the pathogenic mechanism of hyperphagia in lipodystrophy, we measured food-related neural activity by fMRI and investigated subjective feelings of appetite. We found insufficiency of postprandial suppression of food-related neural activity and formation of satiety feelings in patients with lipodystrophy, which might be largely due to leptin deficiency. In March 2013, marketing and manufacturing approval was granted for metreleptin for the treatment of lipodystrophy in Japan on the basis of the results of our investigator-initiated trial. This is the first global approval of leptin formulation. Leptin has potential as a drug for the treatment of more common metabolic diseases including diabetes, hyperlipidemia, and fatty liver.
\end{abstract}

\footnotetext{
K. Ebihara $(\square)$

Institute for Advancement of Clinical and Translational Science,

Kyoto University Hospital, Kyoto, Japan

Division of Endocrinology and Metabolism, Jichi Medical University, Shimotuke, Japan e-mail: kebihara@jichi.ac.jp

K. Nakao, M.D., Ph.D.

Professor, Medical Innovation Center, Kyoto University Graduate

School of Medicine, Kyoto, Japan

(C) The Author(s) 2015

K. Nakao et al. (eds.), Innovative Medicine, DOI 10.1007/978-4-431-55651-0_14
} 
Keywords Leptin $\bullet$ Lipodystrophy $\bullet$ Metreleptin $\bullet$ Lipotoxicity $\bullet$ AMPK (5'-AMPactivated protein kinase) $\bullet$ fMRI (functional magnetic resonance image) $\bullet$ Reward system

\section{Introduction}

Leptin, an adipocyte-derived hormone originally identified from hereditary obese mice (ob/ob mice) [1], plays crucial physiologic roles in the regulation of energy expenditure and food intake [2-6]. In obese animals and subjects, plasma leptin concentrations are increased in proportion to the degree of adiposity [7-9], indicating that leptin is a satiety signal communicating the size of adipose stores to the brain [10-12] and that leptin resistance is related to obesity [7, 13-15]. Leptin deficiency in human subjects is associated with morbid obesity with insulin resistance, indicating the physiological role of leptin in both animal models and humans [16, 17]. Leptin is implicated in a number of manifestations seen in obese animal models [11, 18-21]. In this chapter, we introduce our past basic and clinical studies for clinical application in lipodystrophy and its related diseases.

\section{Transgenic Mice Overexpressing Leptin}

To explore the clinical implications of leptin in vivo, we generated leptin transgenic (LepTg) mice displaying elevated plasma leptin concentrations comparable to those seen in obese subjects [22]. A fusion gene comprising the human SAP promoter upstream of the mouse leptin cDNA coding sequences was designed to target hormone expression to the liver [23, 24]. Overexpression of leptin in the liver resulted in the complete disappearance of both white adipose tissues in mice [22]. Such a phenotype did not occur when transgene expression was targeted to adipose tissue, the endogenous site of leptin production, using adipocyte-specific promoters [25]. The hyperleptinemia seen in these LepTg mice provides a unique experimental system in which the long-term effects of leptin are investigated in vivo [18-22]. LepTg mice exhibit augmented glucose metabolism and increased insulin sensitivity of both skeletal muscle and liver [22], supporting the concept that leptin acts as an antidiabetic hormone in vivo [26-28]. These studies suggest the potential usefulness of leptin treatment of diabetes and obesity.

\section{Crossbreeding Experiment of LepTg Mice with A-ZIPTg Mice}

Lipodystrophy is a disease characterized by a lack of adipose tissue. It can be developed by a genetic abnormality, immune disorder, viral infection, or drugs. Irrespective of the etiology, loss of adipose tissue leads to severe insulin-resistant 
diabetes, hypertriglyceridemia, and fatty liver [29]. The precise mechanism by which this paucity of fat results in these metabolic disorders remains to be elucidated. Plasma leptin concentrations are markedly reduced in patients with lipodystrophy and in rodent models of lipodystrophy [30-33]. Given leptin's antidiabetic action, leptin deficiency may play a role in the pathogenesis of metabolic disorders in lipodystrophy; thus, leptin may be a drug for patients with lipodystrophy.

A mouse model of generalized lipodystrophy (A-ZIPTg mice) was generated by expressing in adipose tissue a protein that inactivates basic zipper transcription factors [32]. To assess the pathophysiological role and therapeutic potential of leptin in metabolic disorders associated with lipodystrophy, we crossed LepTg mice and A-ZIPTg mice to produce doubly transgenic (LepTg/A-ZIPTg) mice virtually lacking adipose tissue and expressing approximately tenfold higher levels of leptin than normal controls [34]. LepTg/A-ZIPTg mice were hypophagic in comparison with A-ZIPTg mice and exhibited decreased hepatic steatosis. Glucose and insulin tolerance tests displayed increased insulin sensitivity and normal glucose tolerance in LepTg/A-ZIPTg mice, which was comparable to LepTg mice. Pair-feeding experiments demonstrated that the effects of leptin were not solely due to decreased food intake. These results demonstrate that leptin can improve insulin resistance and diabetic manifestations in a mouse model of severe systemic lipodystrophy, indicating that leptin is therapeutically useful in the treatment of lipoatrophic diabetes [34].

\section{Leptin Replacement Therapy in Japanese Patients with Lipodystrophy}

Four-month leptin replacement therapy has been reported to improve glucose and lipid metabolism in lipodystrophy patients in the USA [35]. To elucidate the efficacy, safety, and mechanisms underlying leptin replacement therapy in Asian patients with lipodystrophy, we treated seven Japanese patients, two acquired and five congenital types, with a physiological replacement dose of leptin [36, 37]. Leptin replacement therapy dramatically improved fasting glucose levels (mean $\pm \mathrm{SE}$, $172 \pm 20$ to $120 \pm 12 \mathrm{mg} / \mathrm{dl}, \mathrm{P}<0.05$ ) and triglyceride levels (mean $\pm \mathrm{SE}, 700 \pm 272$ to $260 \pm 98 \mathrm{mg} / \mathrm{dl}, \mathrm{P}<0.05$ ) within 1 week. By 2 months, six of seven patients were able to discontinue all antidiabetic drugs, including insulin.

To investigate the underlying mechanism of metabolic improvement by leptin, we evaluated insulin sensitivity using a hyperinsulinemic euglycemic glucose clamp study in human patients (Fig. 1). The glucose infusion rate as an index of insulin sensitivity was distinctly low at baseline but was improved month by month after the initiation of leptin therapy. We also evaluated the glucose tolerance and the ability of insulin secretion with the oral glucose tolerance test (Fig. 2). After 2 months of leptin therapy, the glucose level was dramatically improved and, at the same time, the ability of insulin secretion was also clearly improved. In lipodystrophy, triglyceride accumulates excessively in the cells of non-adipose tissues including the liver and 


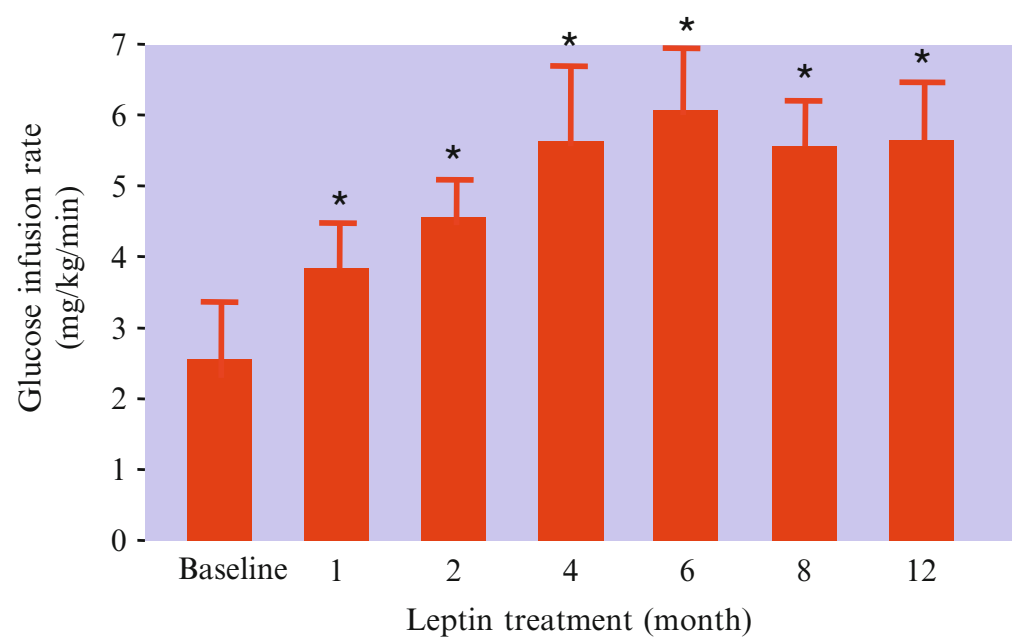

Fig. 1 Glucose infusion rate in a hyperinsulinemic euglycemic glucose clamp study in 10 patients with generalized lipodystrophy. Insulin sensitivity was distinctly low at baseline but improved month by month after the initiation of leptin therapy. ${ }^{*} \mathrm{p}<0.05$ vs baseline
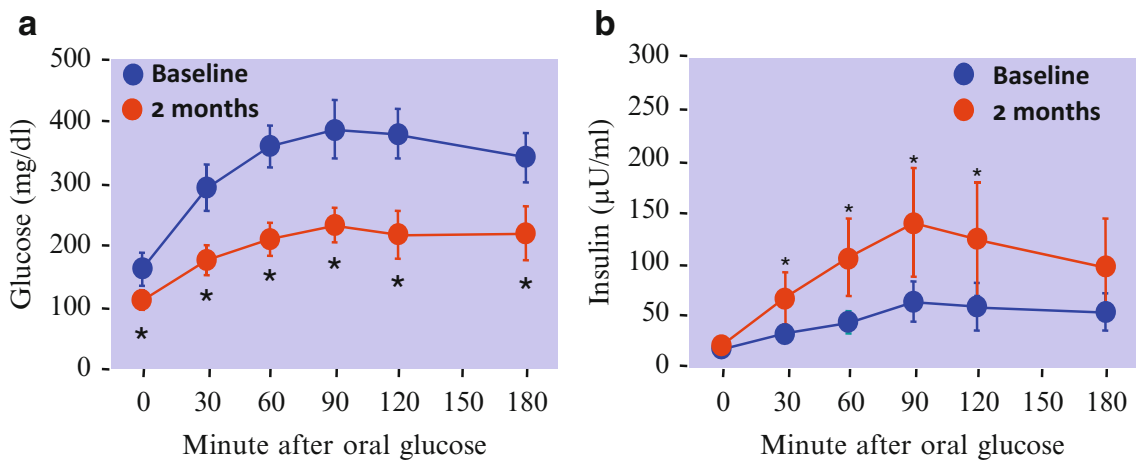

Fig. $275 \mathrm{~g}$ glucose tolerance test in 10 patients with generalized lipodystrophy at baseline and 2 months after the initiation of leptin replacement therapy. (a) Plasma glucose. (b) Insulin levels before and after an oral glucose load. Leptin replacement therapy improved glucose tolerance and insulin secretion. ${ }^{*} \mathrm{p}<0.05$ vs baseline

skeletal muscle [38]. In the liver, the amount of triglyceride accumulation is known to be correlated with the severity of insulin resistance [39]. Triglyceride accumulation in skeletal muscle also leads to insulin resistance [39]. In pancreatic beta cells, triglyceride accumulation is known to impair insulin secretion [39]. Cellular dysfunction caused by ectopic fat deposition has been referred as "lipotoxicity" [40]. To investigate the cancellation of lipotoxicity as a potential mechanism by which 
a

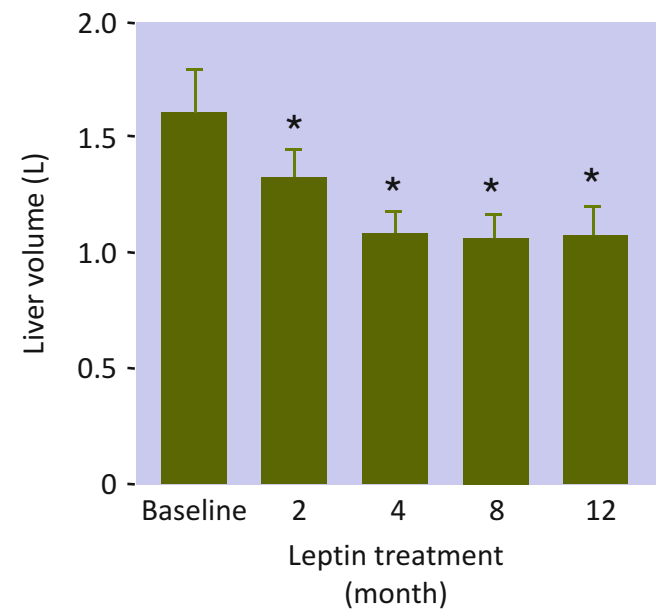

b

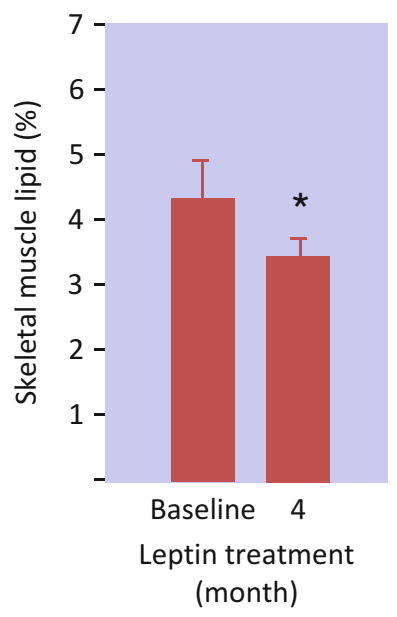

Fig. 3 Ectopic fat deposition in insulin-target tissues. (a) Liver volume calculated by CT in 10 patients with generalized lipodystrophy before and after the initiation of leptin replacement therapy. (b) Skeletal muscle lipid content estimated by MRI before and 4 months after the initiation of leptin replacement therapy. $* \mathrm{p}<0.05$ vs baseline

leptin improves insulin sensitivity and insulin secretion, we evaluated the tissue lipid content in the liver and skeletal muscle in patients with lipodystrophy (Fig. 3). Liver volume as an index of fatty liver was calculated by computed tomography (CT). Leptin therapy effectively decreased liver volume. Skeletal muscle lipid content was estimated by magnetic resonance imaging (MRI). Skeletal muscle lipid content was also significantly decreased after 4 months of leptin therapy. These results suggest that leptin improves insulin sensitivity at least partly by cancellation of lipotoxicity in the liver and skeletal muscle. Although we did not evaluate lipid content in pancreatic beta cells in this study, it is also possible that leptin improves insulin secretion by cancellation of lipotoxicity in beta cells.

We also evaluated subjective feelings of appetite with a $100 \mathrm{~mm}$ visual analog scale [41] in patients before and after the initiation of leptin therapy. On this assessment, participants were instructed to rate how hungry they were by marking on a scale before and after each meal. A higher score indicated a greater extent of hunger. As shown in Fig. 4, the self-reported hunger scores before meals were not different between before and after the initiation of leptin therapy in most patients. In contrast, after meals, the score was effectively suppressed after leptin treatment in most patients. These results indicate that leptin reinforces the formation of satiety feelings after a meal. 

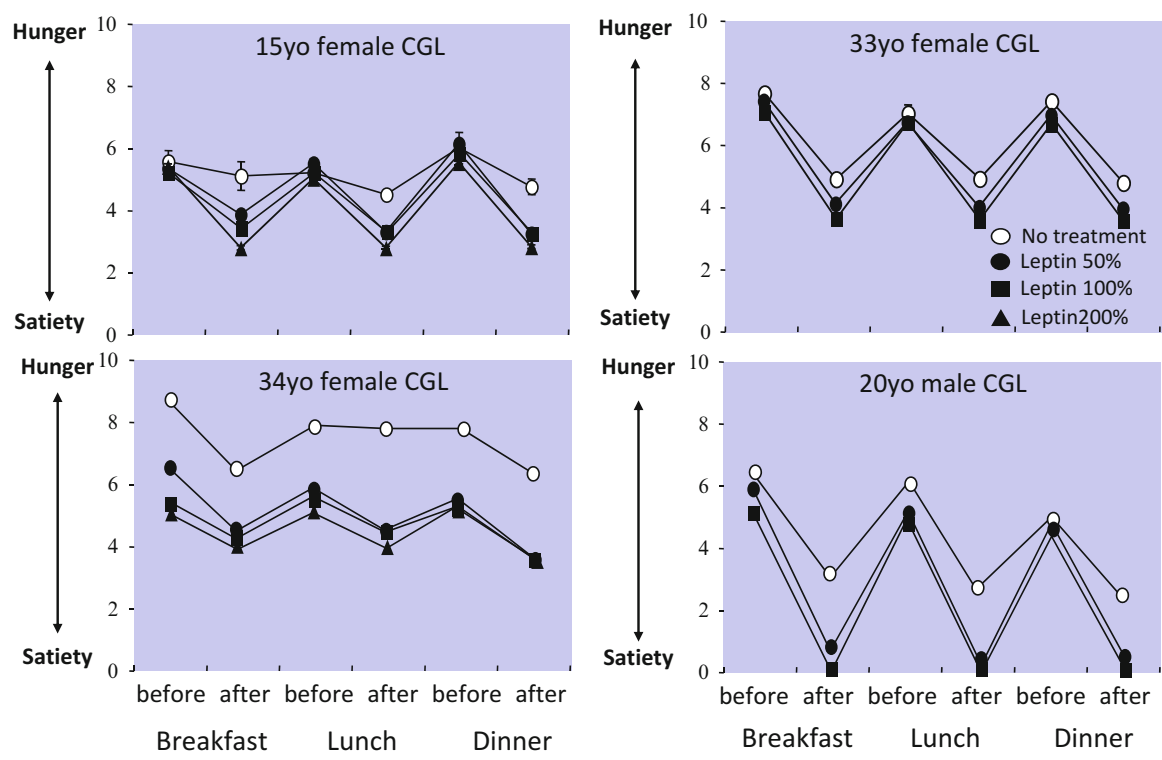

Fig. 4 Subjective appetite feelings evaluated with a $100 \mathrm{~mm}$ visual analog scale in representative patients with generalized lipodystrophy with or without leptin treatment. Patients were treated at $50 \%, 100 \%$, and $200 \%$ of the replacement dose. CGL congenital generalized lipodystrophy

\section{Significance of Hepatic AMPK in the Metabolic Action of Leptin}

Leptin effectively improves insulin sensitivity accompanied by dramatic reduction of fat content in the liver and skeletal muscle in patients with lipodystrophy [35, 37, 38]. Using rodent models, it was demonstrated that leptin activates $5^{\prime}$-AMP-activated protein kinase (AMPK) in the skeletal muscle through both central and direct pathways [42]. AMPK is a heterotrimeric enzyme that is conserved from yeast to humans and functions as a "fuel gauge" to monitor the status of cellular energy. AMPK potently stimulates fatty acid oxidation by inhibiting the activity of acetylCoA carboxylase. Thus, AMPK activation by leptin is a plausible mechanism by which leptin reduces ectopic fat in the skeletal muscle. In addition to the skeletal muscle, recent studies have shown the physiological significance of AMPK in the liver [43, 44]. However, the effect of leptin on hepatic AMPK activity remained to be determined. The role of AMPK in the pathogenesis of metabolic abnormalities in lipodystrophy also remained unclear. We investigated the effect of leptin on hepatic AMPK activities and the pathophysiological role of AMPK in A-ZIPTg mice, a mouse model of generalized lipodystrophy [45].

We demonstrated that leptin activates hepatic AMPK through the central nervous system and alpha-adrenergic sympathetic nerves. AMPK activities were decreased in the fatty liver of A-ZIP/F-1 mice, and leptin administration increased AMPK 
activities in the liver as well as in skeletal muscle with a significant reduction in triglyceride content. Activation of hepatic AMPK with A769662 also led to a decrease in hepatic triglyceride content and blood glucose levels in A-ZIP/F-1 mice. These results indicate that downregulation of hepatic AMPK activities plays a pathophysiological role in the metabolic disturbances of lipodystrophy, and that hepatic AMPK activation is involved in the therapeutic effects of leptin.

\section{fMRI Analysis of Food-Related Brain Activity in Patients with Lipodystrophy}

Lipodystropic patients also exhibit eating disorders, which makes diet therapy difficult [46]. Leptin replacement therapy was shown to suppress appetite in lipodystrophic patients $[46,47]$. However, there is no report on the comparison of eating behaviors between healthy subjects and patients with lipodystrophy. Therefore, the pathophysiological role of leptin in eating disorders in patients with lipodystrophy remains unclear. From experimental studies in human and animals, it has long been established that leptin suppresses energy intake mainly by acting on the hypothalamus [11, 48]. However, there is little information about how the neural networks including the hypothalamus are influenced by leptin signals. Recently the advent of functional neuroimaging techniques such as functional magnetic resonance imaging (fMRI) has been providing novel insights into homeostatic and hedonic aspects of human eating behavior. fMRI measurements of food-related neural activity in congenital leptin-deficient patients were reported [49]. These analyses revealed that leptin treatment modulates neural activity in reward and food-related areas such as the ventral striatum and orbitofrontal cortex.

To reveal the pathogenic mechanism of eating disorders in lipodystrophic patients, we measured food-related neural activity by fMRI scans and investigated subjective feelings of appetite under both fasting and postprandial conditions in patients and age- and sex-matched healthy subjects [51]. In addition, we performed the same sequential analyses in the same patients with leptin replacement therapy [51]. Although there was little difference in the enhancement of neural activity by food stimuli between patients and controls under fasting, postprandial suppression of neural activity was insufficient in many regions of interest including the amygdala, insula, nucleus accumbens, caudate, putamen, and globus pallidus in patients compared with controls. Leptin treatment effectively suppressed postprandial neural activity in many of these regions of interest, whereas it showed little effect under fasting in patients. Consistent with these results, postprandial formation of satiety feelings was insufficient in patients compared with controls, which was effectively reinforced by leptin treatment. These results demonstrate the insufficiency of postprandial suppression of food-related neural activity and formation of satiety feelings in patients with lipodystrophy, which might be largely due to leptin deficiency. This study also demonstrated that leptin has little involvement in the regulation of neural activity and eating behavior under fasting, whereas leptin plays a significant role in 
these regulations under postprandial conditions. We found that leptin suppressed neural activity in regions involved in the reward system such as the amygdala, hippocampus, NcA, and caudate. Further study is needed to elucidate the role of the reward system on appetite regulation by leptin.

\section{Conclusions}

Metreleptin is an analog of human leptin originally developed by Amgen and has been used for treatment in patients with lipodystrophy also in Japan. In July 2012, Shionogi originally filed a New Drug Application (NDA), which was based on the results of our investigator-initiated trial conducted by the Kyoto University Graduate School of Medicine with assistance from the Translational Research Center (the current Institute for Advancement of Clinical and Translational Science) at Kyoto University Hospital. In March 2013, marketing and manufacturing approval was granted by the Japanese Ministry of Health, Labour and Welfare for subcutaneous metreleptin for the treatment of lipodystrophy. This is the first global approval of leptin formulation [51]. In patients with lipodystrophy, leptin improved insulin resistance, hypertriglyceridemia, and fatty liver. We have demonstrated the therapeutic usefulness of leptin in insulin-deficient diabetes, non-obese type 2 diabetes, type 2 diabetes with mild obesity, hypertriglyceridemia, and non-alcoholic fatty liver [45, 52-56]. Leptin has potential as a drug for the treatment of more common metabolic diseases including diabetes, hyperlipidemia, and fatty liver.

Open Access This chapter is distributed under the terms of the Creative Commons Attribution Noncommercial License, which permits any noncommercial use, distribution, and reproduction in any medium, provided the original author(s) and source are credited.

\section{References}

1. Zhang Y, Proenca R, Maffei M, Barone M, Leopold L, Friedman JM (1994) Positional cloning of the mouse obese gene and its human homologue. Nature 372:425-432

2. Friedman JM, Halaas JL (1998) Leptin and the regulation of body weight in mammals. Nature 395:763-770

3. Pelleymounter MA, Cullen MJ, Baker MB, Hecht R, Winters D, Boone T, Collins F (1995) Effects of the obese gene product on body weight regulation in ob/ob mice. Science 269:540-543

4. Halaas JL, Gajiwala KS, Maffei M, Cohen SL, Chait BT, Rabinowitz D, Lallone RL, Burley SK, Friedman JM (1995) Weight-reducing effects of the plasma protein encoded by the obese gene. Science 269:543-546

5. Campfield LA, Smith FJ, Guisez Y, Devos R, Burn P (1995) Recombinant mouse OB protein: evidence for a peripheral signal linking adiposity and central neural networks. Science 269:546-549

6. Satoh N, Ogawa Y, Katsuura G, Numata Y, Tsuji T, Hayase M, Ebihara K, Masuzaki H, Hosoda $\mathrm{K}$, Yoshimasa Y et al (1999) Sympathetic activation of leptin via the ventromedial hypothalamus: leptin-induced increase in catecholamine secretion. Diabetes 48:1787-1793 
7. Frederich RC, Hamann A, Anderson S, Lollmann B, Lowell BB, Flier JS (1995) Leptin levels reflect body lipid content in mice: evidence for diet-induced resistance to leptin action. Nat Med 1:1311-1314

8. Maffei M, Halaas J, Ravussin E, Pratley RE, Lee GH, Zhang Y, Fei H, Kim S, Lallone R, Ranganathan S et al (1995) Leptin levels in human and rodent: measurement of plasma leptin and ob RNA in obese and weight-reduced subjects. Nat Med 1:1155-1161

9. Considine RV, Sinha MK, Heiman ML, Kriauciunas A, Stephens TW, Nyce MR, Ohannesian JP, Marco CC, McKee LJ, Bauer TL et al (1996) Serum immunoreactive-leptin concentrations in normal-weight and obese humans. N Engl J Med 334:292-295

10. Isse N, Ogawa Y, Tamura N, Masuzaki H, Mori K, Okazaki T, Satoh N, Shigemoto M, Yoshimasa Y, Nishi S et al (1995) Structural organization and chromosomal assignment of the human obese gene. J Biol Chem 270:27728-27733

11. Satoh N, Ogawa Y, Katsuura G, Tsuji T, Masuzaki H, Hiraoka J, Okazaki T, Tamaki M, Hayase M, Yoshimasa Y et al (1997) Pathophysiological significance of the obese gene product, leptin, in ventromedial hypothalamus (VMH)-lesioned rats: evidence for loss of its satiety effect in VMH-lesioned rats. Endocrinology 138:947-954

12. Imagawa K, Numata Y, Katsuura G, Sakaguchi I, Morita A, Kikuoka S, Matumoto Y, Tsuji T, Tamaki M, Sasakura K et al (1998) Structure-function studies of human leptin. J Biol Chem 273:35245-35249

13. Caro JF, Kolaczynski JW, Nyce MR, Ohannesian JP, Opentanova I, Goldman WH, Lynn RB, Zhang PL, Sinha MK, Considine RV (1996) Decreased cerebrospinal-fluid/serum leptin ratio in obesity: a possible mechanism for leptin resistance. Lancet 348:159-161

14. Halaas JL, Boozer C, Blair-West J, Fidahusein N, Denton DA, Friedman JM (1997) Physiological response to long-term peripheral and central leptin infusion in lean and obese mice. Proc Natl Acad Sci U S A 94:8878-8883

15. Tanaka T, Masuzaki H, Yasue S, Ebihara K, Shiuchi T, Ishii T, Arai N, Hirata M, Yamamoto H, Hayashi $\mathrm{T}$ et al (2007) Central melanocortin signaling restores skeletal muscle AMP-activated protein kinase phosphorylation in mice fed a high-fat diet. Cell Metab $5: 395-402$

16. Montague CT, Farooqi IS, Whitehead JP, Soos MA, Rau H, Wareham NJ, Sewter CP, Digby JE, Mohammed SN, Hurst JA et al (1997) Congenital leptin deficiency is associated with severe early-onset obesity in humans. Nature 387:903-908

17. Strobel A, Issad T, Camoin L, Ozata M, Strosberg AD (1998) A leptin missense mutation associated with hypogonadism and morbid obesity. Nat Genet 18:213-215

18. Yura S, Ogawa Y, Sagawa N, Masuzaki H, Itoh H, Ebihara K, Aizawa-Abe M, Fujii S, Nakao K (2000) Accelerated puberty and late-onset hypothalamic hypogonadism in female transgenic skinny mice overexpressing leptin. J Clin Invest 105:749-755

19. Aizawa-Abe M, Ogawa Y, Masuzaki H, Ebihara K, Satoh N, Iwai H, Matsuoka N, Hayashi T, Hosoda K, Inoue G et al (2000) Pathophysiological role of leptin in obesity-related hypertension. J Clin Invest 105:1243-1252

20. Elefteriou F, Takeda S, Ebihara K, Magre J, Patano N, Kim CA, Ogawa Y, Liu X, Ware SM, Craigen WJ et al (2004) Serum leptin level is a regulator of bone mass. Proc Natl Acad Sci U S A 101:3258-3263

21. Suganami T, Mukoyama M, Mori K, Yokoi H, Koshikawa M, Sawai K, Hidaka S, Ebihara K, Tanaka T, Sugawara A et al (2005) Prevention and reversal of renal injury by leptin in a new mouse model of diabetic nephropathy. FASEB J 19:127-129

22. Ogawa Y, Masuzaki H, Hosoda K, Aizawa-Abe M, Suga J, Suda M, Ebihara K, Iwai H, Matsuoka N, Satoh N et al (1999) Increased glucose metabolism and insulin sensitivity in transgenic skinny mice overexpressing leptin. Diabetes 48:1822-1829

23. Ogawa Y, Itoh H, Tamura N, Suga S, Yoshimasa T, Uehira M, Matsuda S, Shiono S, Nishimoto H, Nakao K (1994) Molecular cloning of the complementary DNA and gene that encode mouse brain natriuretic peptide and generation of transgenic mice that overexpress the brain natriuretic peptide gene. J Clin Invest 93:1911-1921 
24. Masuzaki H, Ogawa Y, Isse N, Satoh N, Okazaki T, Shigemoto M, Mori K, Tamura N, Hosoda K, Yoshimasa Y et al (1995) Human obese gene expression. Adipocyte-specific expression and regional differences in the adipose tissue. Diabetes 44:855-858

25. Ioffe E, Moon B, Connolly E, Friedman JM (1998) Abnormal regulation of the leptin gene in the pathogenesis of obesity. Proc Natl Acad Sci U S A 95:11852-11857

26. Kamohara S, Burcelin R, Halaas JL, Friedman JM, Charron MJ (1997) Acute stimulation of glucose metabolism in mice by leptin treatment. Nature 389:374-377

27. Liu L, Karkanias GB, Morales JC, Hawkins M, Barzilai N, Wang J, Rossetti L (1998) Intracerebroventricular leptin regulates hepatic but not peripheral glucose fluxes. J Biol Chem 273:31160-31167

28. Cusin I, Zakrzewska KE, Boss O, Muzzin P, Giacobino JP, Ricquier D, Jeanrenaud B, Rohner-Jeanrenaud F (1998) Chronic central leptin infusion enhances insulin-stimulated glucose metabolism and favors the expression of uncoupling proteins. Diabetes 47:1014-1019

29. Goldstein BJ (1994) Syndrome of extreme insulin resistance. In: Kahn CR, Weir GC (eds) Joslin's diabetes mellitus. Lea \& Febiger, Philadelphia

30. Andreelli F, Hanaire-Broutin H, Laville M, Tauber JP, Riou JP, Thivolet C (2000) Normal reproductive function in leptindeficient patients with lipoatrophic diabetes. J Clin Endocrinol Metab 85:715-719

31. Pardini VC, Victoria IM, Rocha SM, Andrade DG, Rocha AM, Pieroni FB, Milagres G, Purisch S, Velho G (1998) Leptin levels, beta-cell function, and insulin sensitivity in families with congenital and acquired generalized lipoatrophic diabetes. J Clin Endocrinol Metab 83:503-508

32. Moitra J, Mason MM, Olive M, Krylov D, Gavrilova O, Marcus-Samuels B, Feigenbaum L, Lee E, Aoyama T, Eckhaus M et al (1998) Life without white fat: a transgenic mouse. Genes Dev 12:3168-3181

33. Shimomura I, Hammer RE, Richardson JA, Ikemoto S, Bashmakov Y, Goldstein JL, Brown MS (1998) Insulin resistance and diabetes mellitus in transgenic mice expressing nuclear SREBP-1c in adipose tissue: model for congenital generalized lipodystrophy. Genes Dev 12:3182-3194

34. Ebihara K, Ogawa Y, Masuzaki H, Shintani M, Miyanaga F, Aizawa-Abe M, Hayashi T, Hosoda K, Inoue G, Yoshimasa Y et al (2001) Transgenic overexpression of leptin rescues insulin resistance and diabetes in a mouse model of lipoatrophic diabetes. Diabetes 50:1440-1448

35. Oral EA, Simha V, Ruiz E, Andewelt A, Premkumar A, Snell P, Wagner AJ, DePaoli AM, Reitman ML, Taylor SI et al (2002) Leptin-replacement therapy for lipodystrophy. N Engl J Med 346:570-578

36. Ebihara K, Masuzaki H, Nakao K (2004) Long-term leptinreplacement therapy for lipoatrophic diabetes. N Engl J Med 351:615-616

37. Ebihara K, Kusakabe T, Hirata M, Masuzaki H, Miyanaga F, Kobayashi N, Tanaka T, Chusho H, Miyazawa T, Hayashi T et al (2007) Efficacy and safety of leptin-replacement therapy and possible mechanisms of leptin actions in patients with generalized lipodystrophy. J Clin Endocrinol Metab 92:532-541

38. Petersen KF, Oral EA, Dufour S, Befroy D, Ariyan C, Yu C, Cline GW, DePaoli AM, Taylor SI, Gorden P et al (2002) Leptin reverses insulin resistance and hepatic steatosis in patients with severe lipodystrophy. J Clin Invest 109:1345-1350

39. Shulman GI (2000) Cellular mechanisms of insulin resistance. J Clin Invest 106:171-176

40. Unger RH (1995) Lipotoxicity in the pathogenesis of obesity-dependent NIDDM. Genetic and clinical implications. Diabetes 44:863-870

41. Chaput JP, Gilbert JA, Gregersen NT, Pedersen SD, Sjödin AM (2010) Comparison of 150-mm versus 100-mm visual analogue scales in free living adult subjects. Appetite 49:691-695

42. Minokoshi Y, Kim YB, Peroni OD, Fryer LG, Müller C, Carling D, Kahn BB (2002) Leptin stimulates fatty-acid oxidation by activating AMP-activated protein kinase. Nature 415:339-343 
43. Assifi MM, Suchankova G, Constant S, Prentki M, Saha AK, Ruderman NB (2005) AMP-activated protein kinase and coordination of hepatic fatty acid metabolism of starved/ carbohydrate-refed rats. Am J Physiol Endocrinol Metab 289:E794-E800

44. Shaw RJ, Lamia KA, Vasquez D, Koo SH, Bardeesy N, Depinho RA, Montminy M, Cantley LC (2005) The kinase LKB1 mediates glucose homeostasis in liver and therapeutic effects of metformin. Science 310:1642-1646

45. Miyamoto L, Ebihara K, Kusakabe T, Aotani D, Yamamoto-Kataoka S, Sakai T, Aizawa-Abe M, Yamamoto Y, Fujikura J, Hayashi T et al (2012) Leptin activates hepatic 5'-AMP-activated protein kinase through sympathetic nervous system and $\alpha 1$-adrenergic receptor: a potential mechanism for improvement of fatty liver in lipodystrophy by leptin. J Biol Chem 287:40441-40447

46. McDuffie JR, Riggs PA, Calis KA, Freedman RJ, Oral EA, DePaoli AM, Yanovski JA (2004) Effects of exogenous leptin on satiety and satiation in patients with lipodystrophy and leptin insufficiency. J Clin Endocrinol Metab 89:4258-4263

47. Moran SA, Patten N, Young JR, Cochran E, Sebring N, Reynolds J, Premkumar A, Depaoli AM, Skarulis MC, Oral EA et al (2004) Changes in body composition in patients with severe lipodystrophy after leptin replacement therapy. Metabolism 53:513-519

48. Schwartz MW, Seeley RJ, Campfield LA, Burn P, Baskin DG (1996) Identification of targets of leptin action in rat hypothalamus. J Clin Invest 98:1101-1106

49. Farooqi IS, Bullmore E, Keogh J, Gillard J, O'Rahilly S, Fletcher PC (2007) Leptin regulates striatal regions and human eating behavior. Science 317:1355

50. Aotani D, Ebihara K, Sawamoto N, Kusakabe T, Aizawa-Abe M, Kataoka S, Sakai T, Iogawa H, Ebihara C, Fujikura $\mathbf{J}$ et al (2012) Functional magnetic resonance imaging analysis of food-related brain activity in patients with lipodystrophy undergoing leptin replacement therapy. J Clin Endocrinol Metab 97:3663-3671

51. Chou K, Perry CM (2013) Metreleptin: first global approval. Drugs 73:989-997

52. Miyanaga F, Ogawa Y, Ebihara K, Hidaka S, Tanaka T, Hayashi S, Masuzaki H, Nakao K (2003) Leptin as an adjunct of insulin therapy in insulin-deficient diabetes. Diabetologia 4610:1329-1337

53. Naito M, Fujikura J, Ebihara K, Miyanaga F, Yokoi H, Kusakabe T, Yamamoto Y, Son C, Mukoyama M, Hosoda K et al (2011) Therapeutic impact of leptin on diabetes, diabetic complications, and longevity in insulin-deficient diabetic mice. Diabetes 60:2265-2273

54. Kusakabe T, Tanioka H, Ebihara K, Hirata M, Miyamoto L, Miyanaga F, Hige H, Aotani D, Fujisawa T, Masuzaki H et al (2009) Beneficial effects of leptin on glycaemic and lipid control in a mouse model of type 2 diabetes with increased adiposity induced by streptozotocin and a high-fat diet. Diabetologia 52:675-683

55. Matsuoka N, Ogawa Y, Masuzaki H, Ebihara K, Aizawa-Abe M, Satoh N, Ishikawa E, Fujisawa Y, Kosaki A, Yamada K et al (2001) Decreased triglyceride-rich lipoproteins in transgenic skinny mice overexpressing leptin. Am J Physiol Endocrinol Metab 280:E334-E339

56. Yamamoto-Kataoka S, Ebihara K, Aizawa-Abe M, Nishio M, Kusakabe T, Yamamoto Y, Aotani D, Sakai T, Zhao M, Ebihara C et al (2014) Leptin improves fatty liver independently of insulin sensitization and appetite suppression in hepatocyte-specific Pten-deficient mice with insulin hypersensitivity. Horm Metab Res (in press) 